\title{
A Call to Strengthen the Law on Insanity in Kenya
}

Jentrix Wanyama*

\begin{abstract}
The legal presumption of sanity is unfortunately sometimes disproved. Indeed, there are ailments that rob some members of society the ability to be responsible moral agents. When they err, confusion arises as to how to treat the situation. The defence of insanity is the law's response to this peculiarity. This paper, through a study of the defence, argues that the current position in Kenya needs to be reviewed and reformed, with emphasis on the need for psychiatric expertise in the process.
\end{abstract}

\section{Introduction}

That the law is 'servant and not master', ought not to surprise the modern thinker, ${ }^{1}$ wrote Charles E Clark. Legal reform aids greatly in this task. It is among those tools used to ensure that laws are in harmony with current situations, that they are as simple as possible to understand and that they are of good standard. For the best standards possible, we want the law to 'alter when alteration it finds'.

Mental health law is an area that has arguably been long bereft of legal reform in Kenya. ${ }^{3}$ One of the areas in law that has suffered from this dry spell is the law on insanity. Insanity is a legal phenomenon that dangerously arches into mental health territory, particularly psychiatry. Though it is common for legal practitioners to constantly interact with many other disciplines, ${ }^{4}$ cases involving accused persons who plead insanity pose a particularly difficult challenge.

\footnotetext{
* 'The author is an LL.B student at the Strathmore University Law School in Nairobi, Kenya.

Clark CE, 'The Function of Law in a Democratic Society', University of Chicago Law Review, 393.

Shakespeare W, Sonnet 116.

Kenya, for instance, only launched its maiden Mental Health Policy in 2015. See Ministry of Health, 'Kenya Mental Health Policy, 2015-2030.'

4 Areeda P, 'Always a borrower: law and other disciplines, Duke Law Journal, 1988, 1029.
} 
To begin with, the very nature of the crimes tends to be very disturbing. ${ }^{5}$ A famous example is that of the American John Hinckley, who attempted to assassinate President Reagan. Hinckley believed that his assassination attempt was a love offering to popular actress Jodie Foster - whom he had never met. Previously, he had watched one of her movies about fifteen times consecutively, moved across the country to where she lived, and even enrolled at the same college as she. Closer home, a Kenyan reader might remember self-confessed serial killer Charles Onyancha who claimed that he could stupefy victims by mere eye conduct. $^{6}$

Because of the disturbing nature of some of the high-profile crimes committed under the pretext of insanity, a battle of wills ensues. ${ }^{7}$ While the public often cries for blood, ${ }^{8}$ the law grimaces in the knowledge of the defendant's possible lack of mens rea, its principles of presumption of innocence, fair trial and equality before the law — all the while wishing to dispense justice. ${ }^{9}$ It is truly a dilemma. Sadly, the response of courts and legislators alike has been to hold on to rules created by their predecessors, ${ }^{10}$ not unlike a child hoping that the problem will magically go away. Perhaps the consolation is that such cases are rare, after all. ${ }^{11}$ This is evidenced by the fact that in spite of recent psychiatric advancements, the substance of the insanity defence in Kenya ${ }^{12}$ and many other jurisdictions has remained largely untouched; leaving the courts to resort to what

5 There are many examples such as cannibalism, a blood- curdling and notoriously popular manifestation in insanity pleas. The offenders tend to go as far as storing the human flesh in their refrigerators for later consumption. (Such as Albert Fish, the infamous American 'boogey man' who was eventually found guilty of murder and was sentenced to capital punishment.)

6 'Confessed Killer Philip Onyancha's tape played', Daily Nation, 4 March 2015.

7 Only a very small percentage of insanity pleas succeed, it is assumed that the majority of the pleas are untrue or weak at best, see Cevallos D, 'Don't rely on insanity defense', $C N N$, Updated on 17 July 2015. http://edition.cnn.com/2015/02/11/opinion/cevallos-insanity-defense/ on 10 August 2016.

8 In high profile cases, a return of guilty but insane or not guilty on grounds of insanity usually causes public furore. This was the case in the M'Naughten case.

9 'Moral responsibility', Stanford Encyclopaedia of Pbilosophy, 2014.

10 The most popular of these being the M'Naughten rules, discussed extensively later in this paper. It is fair to note, however, that in jurisdictions where stricter alternative insanity rules have been formulated in times of public outrage, the new rules have tended to be short-lived. The high threshold set usually gets a tongue-lashing forcing the courts to once more change them, going back to the original rules with only slight variations. The Durham Rules, which were a result of Durbam $v$ United States (214 F.2d 862) would form an appropriate study sample.

11 That is, high- profile insanity cases that tend to capture the public's imagination.

12 Mainly section 12, Penal Code (81 of 1948). 
commentators have called 'benevolent conspiracy ${ }^{\text {'13 }}$ where a strict reading of the existing laws would result in an obvious injustice. ${ }^{14}$

One excuse given for this legal stagnation is that the law of insanity is a 'difficult subject', 15 since it involves reaching an understanding of the human mind. This is almost impossible for, as Cicero put it: 'The thought of man is not triable, for the devil himself knoweth not the intendment of man. ${ }^{16}$ It is true that challenges surrounding the defence are weighty. On one hand, reliance on the medical understanding of the mind presents a challenge of universal acceptance since unfortunately, it has not been possible to subject this knowledge to empirical validation. ${ }^{17}$ In addition, the approaches taken by mental health experts vary a great deal.

This leaves the court in a dilemma, since it lacks expertise of its own. Lastly, the punitive and preventative nature of criminal law is seemingly compromised when presented with offenders who are regarded as being 'abnormal'. The court finds itself in a quagmire having to consider the need to protect society from potential harm and at the same time be equitable to the offender, a possible victim of mental illness. ${ }^{18}$

However, the law cannot afford to be lax in its mandate. That would be an affront not only to the very purpose of law, but also to the people whom it is supposed to serve. For legal practitioners, the task is to 'proceed with fortitude no matter what the task at hand is'. ${ }^{19}$ 'This paper therefore suggests that even when faced with the seemingly unfeasible subject that is the law on insanity, the law must continue to be a servant in offering clear yet meaningful, wellresearched guidelines for society.

13 Baker D, Glanville Williams Textbook of Criminal Law, Sweet \& Maxwell, 4ed, London, 2015, 599.

14 There has been no amendment made to the provisions in Section 12 of the Penal Code, which was enacted in 1948 nor to Section 168 of the Criminal Procedure Code.

15 Low, Jeffries and Bonnie, Criminal Law, 655.

16 As quoted by Chief Justice Brian in Greene $v$ The Queen (1468).

17 Low, Jefffries, Bonnie, Criminal Law, 656.

18 Mathew Shaw breaks down the question of interaction of a mentally ill offender with society into three components; the risk posed by such individuals, the varying degrees of risk in respect to context, and, the manageability of the risk. See Shaw MF, After the Insanity Defense : When the Acquitted Return to the Community, LFB Scholarly Publishing LLC, 2006, 2.

19 Stransham-Ford v Minister of Justice and Correctional Services and Others (27401/15) [2015] ZAGPPHC 230, para1. 


\section{The Tradition of Something Old, Something Borrowed, Something New}

An old English couplet directs that on her wedding day, a bride should wear 'something old, something new, something borrowed, something blue'. ${ }^{20}$ These, ideally, were trinkets given to the bride by her family. The 'something old' symbolised continuity and protection from the evil eye believed to cause infertility. The 'something borrowed' symbolised borrowed and shared happiness for the marriage while 'something new' symbolised optimism for the future. Lastly, 'something blue' symbolised purity, love and fidelity.

The rhyme has been used by writers to analogise the past, present and future of various subjects. In this paper, the English wedding tradition discussed above is used as an analogy in studying the history, development and weaknesses of the defence of insanity. A critique of the defence is attempted with a view of demonstrating a need for reforms.

The first part of the paper, something old, tracks the history of insanity in society and how the law came to decide on cases involving insanity. The paper looks at the developments that led to the formulation of the plea followed by a study of the substantive law as it stands. This is done so as to identify the needs that led to this legal headache and to demonstrate a need for continuity in the spirit and principles that birthed this law.

In the second part of the paper, something borrowed, the procedural aspect of the current law is considered. The position of this paper is that Kenyan law could borrow a leaf from foreign jurisdictions in terms of the procedure followed in the disposal of the few persons who are proven to be guilty but insane. Here, a look into the insanity defence in England gives the reader a view into the origin of Kenya's position and serves to show that Kenya is living in the past as far as procedural provisions go.

In the final part of the paper, something new, the suggestion is that a keener look at psychiatry could yield some relief to the confusion present in both the substantive and procedural law on the insanity plea. Here, suggestions as to how to achieve this in the Kenyan context are rendered.

20 Brierly GH, Bye-gones, Relating to Wales and the Border Counties 3, Oswestry and Wrexham: Woodall, Minshall\& Co., 1876,136. 


\section{Something Old: Development of the Defence of Insanity}

Scottish artist and curator James Drummond once wrote that 'no weapon... has, at different periods and among different nations, assumed so many forms as the shield'. ${ }^{21}$ Under law, Drummond's observation easily describes the defence of insanity. Indeed, the defence has had a long and often controversial history, manifesting itself in various jurisdictions in different forms. Other than studying the history of the defence, it is the purpose of this discussion to demonstrate that all along, it has been nearly impossible to separate law and medicine in matters of insanity. The proposition made is that they developed side by side, and as such ought to be maintained that way.

An interaction between mental illness and the law can be traced back to the Neolithic period. Perforated skulls from the era have often been discovered by archaeologists indicating that as early as the Stone Age, society was in need of treatment of mental maladies. ${ }^{22}$ Trepanation (or trephination) was the surgical intrusion into a patient's head by chipping a hole into it. While the stone age humans believed that incisions into the head made room for evil spirits to leave the individual, ${ }^{23}$ fifteenth century iconography reveals that mentally ill patients underwent trepanation in the hope of removing 'the stone of madness' that was then thought to be the cause of mental illness. Even in these early times about which we have scant recorded information, scholars have stated that the trepanned skulls are evidence of some legal authority on the matter, since to have the authority to drill into a person's head is surely to have complete authority over him; and an accepted authority at that. ${ }^{24}$

Centuries later in England, we must first turn to Bracton, the 'flower and crown of English Jurisprudence'. ${ }^{25}$ It was he who introduced the concept of mens rea into English legal discourse, triggering successors to conclude that if one was not aware of his faculties, this negated his mens rea, and consequently, his culpability. One of these successors is among the earliest English jurists on record on

21 Drummond J, Highland targets and other shields, Neil and Company, Edinburgh, 1873, 3.

22 Irving J, 'Trephination', Ancient History Encyclopaedia, Published on 1 May 2013 at http://www.ancient.eu/Trephination/ on 13 August 2016.

23 Foerschner A, 'Thehistory of mental illness: From skull drills to happy pills', Inquiries Journal,(2), 2010, 1.

24 Thiher A, Corporealities: Discourses of disability : revels in madness : Insanity in medicine and literature, University of Michigan Press, 2009, 1.

25 That is, the famous jurist Bracton, as described by Plucknett in Plucknett T, A Concise History of the Common Law, The Law Book Exchange Ltd., 2001, 258. 
the matter-Lord Hale. In his revered treatise The History of Pleas to the Crown, he asserted that 'the consent of the will is that which renders human actions either commendable or culpable... it follows that, where there is a total defect of the understanding, there is no free act of the will' ${ }^{26}$ Hale published his treatise in the 1670s, and this forgiving, almost dismissive attitude toward persons suffering from mental illnesses went almost unquestioned for years.

A clear example is in Justice Tracey's judgement in the 1724 case against one Arnold, a known madman. ${ }^{27}$ Arnold planned and executed the murder of a nobleman believing that the nobleman was 'the occasion of all troubles in England'. Justice Tracey held that to prove insanity, it must be shown that the defendant is totally deprived of his understanding and memory, not aware of his actions, and unable to distinguish between good and evil. Justice Tracey further stated that such a person could never be the subject of punishment, likening them to 'an infant... brute, or a wild beast'. ${ }^{28}$

This position changed in 1800 when ex-soldier James Hadfield, believing that he needed to be executed by the Government so as to advance the Second Coming of Christ, shot at the King in public. Though he missed, he was immediately charged with treason. Doctors testified that his delusions were a result of head injuries sustained in battle. For this reason, the court found him not guilty. However, what this paper terms as the 'forgiving, almost dismissive' attitude characteristic of the courts in insanity cases was no more. Unlike in previous insanity cases, Hadfield was not released into the care of his family. An attempt on the King's life was treason, after all. ${ }^{29}$ This prompted the passing of a new legislation, the Criminal Lunatics Act of 1800, to enable the court to order the detention of Hadfield.

Even in the English context, it should be noted that Hadfield's case took place in an era where psychiatric hospitals were rare, ${ }^{30}$ and hence the Criminal Lunatics Act, in dictating that a deluded person be kept 'in such place and in such manner as to the court shall see fit, until His Majesty's pleasure shall be known, ${ }^{31}$ was consistent with this fact, as opposed to a situation where the statute might have been clearer.

\footnotetext{
26 Hale M, The History of Pleas to the Crown, Philadelphia, 1847, 14.

${ }_{27}$ Rex $v$ Arnold (1724), The United Kingdom (unreported).

28 Justice Tracey's formulation came to be known as the 'wild beast test'.

29 Eigen, JP, Witnessing Insanity: Madness and mad-doctors in the English Court, Yale University Press, 1995.

${ }^{30}$ Moran R, 'The origin of insanity as a special verdict: The Trial for Treason of James Hadfield (1800)', Law \& Society Review, 487.

31 Criminal Lunatics Act of 1800.
} 
The law regarding insanity as a defence against criminal liability in Kenya can be found in statute and case law. It is essential to identify the relevant sources of law on insanity for a clear understanding of the legal definition of insanity. The legal definition of insanity is clearly distinguishable from the medical understanding of the term. ${ }^{32}$ In fact, the term is now obsolete in medical circles. ${ }^{33}$ The modern legal understanding of insanity is derived ${ }^{34}$ from the M'Naughten rules. ${ }^{35}$

Daniel M'Naughten was a deluded man who claimed to have been tormented by the 'Tories' into planning the assassination of the Prime Minister. He mistook the Prime Minister's secretary for the Prime Minister himself and shot him, causing fatal wounds. He was found innocent by reason of insanity. ${ }^{36}$ The case had been a high profile one with extensive media coverage. At this finding, there was public uproar with concerns that the court had set bad precedent. Queen Victoria herself had been the target of several assassination attempts and it was feared that future attackers would be better protected from liability. ${ }^{37}$ The House of Lords requested the judges to formulate rules pertaining to the insanity defence. These rules came to be known as the M'Naughten rules and are discussed below.

\section{i. $\quad$ There was a defect in reasoning}

The defendant has to prove that he or she was suffering from a defect of the mind at the time of crime. As per Justice Devlin in $R v$ Kemp, ${ }^{38}$ 'the law is not concerned with the brain, but with the mind, in the sense that 'mind' is used in its ordinary meaning... in my judgement the condition of the brain is irrelevant'.

The question arises as to what exactly is meant by there being a 'defect in reasoning'. The apparent position in Kenya is that the defect has to be proved to have been the result of a disease of the mind. ${ }^{39}$ There exists no nationally ac-

\footnotetext{
32 Ormerod D, Smith \& Hogan criminal law; Cases and materials, 10ed, Oxford University Press, Oxford, 2009, 424.

33 Lumumba PLO, A handbook in criminal procedure, Law Africa, Nairobi, 2009, 127.

34 Lumumba, $A$ handbook in criminal procedure, 126.

35 There are about twelve variants to the spelling of M'Naughten's name. Scholars are unsure of the original version. In this paper, this spelling, used in the English Law Reports, is adopted. See Low P, Jeffries CJ, Bonnie RJ, Criminal Law; Cases and Materials, 2ed, The Foundation Press Inc., New York, $1968,657$.

36 M'Naughten's case (1843), House of Lords of the United Kingdom.

37 Low, Jeffrieses and Bonnie, Criminal Law, 670.

38 R $v$ Kemp (1957), Queen's Bench of the United Kingdom.

39 Musyoka, Criminal Law, 106- 107.
} 
cepted standard, as the Mental Health Bill of 2015 fails to give a clear definition of this. However, the United Kingdom Mental Health Act of 2007 elaborates on the definition of mental illness as follows:

'mental illness means a condition that seriously impairs, either temporarily or permanently, the mental functioning of a person and is characterised by the presence in the person of any one or more of the following symptoms: (a) delusions, (b) hallucinations, (c) serious disorder of thought form, (d) a severe disturbance of mood, (e) sustained or repeated irrational behaviour indicating the presence of any one or more of the symptoms referred to in paragraphs a, b, c'.40

Further, the World Health Organisation lists schizophrenia, depression and defects due to drug abuse, as just a few of the existing mental disorders and goes on to state that most of them are treatable. ${ }^{41}$

A clear, accepted definition is desirable for Kenya for purposes of uniformity. This would be better carried out with the involvement of experts in mental health, and a representative body such that there are no divergent definitions by different practitioners. The example given here is the United States of America, which has the American Union of Psychiatrists. ${ }^{42}$

Psychiatric experts also ought not be locked out of the court process when it comes to defendants who are suspected of being mentally ill. An example is in the recent case of Leonard Mwangemi Munyasia v Republic, where the learned justices stressed the need for Kenyan courts to adopt the use of psychiatric evidence as a matter of good practice. ${ }^{43}$ Here, the accused found some police officers who were on duty seated on a bench. Without saying anything, he joined them. He then stabbed one of them without provocation or warning. He later claimed not to have any recollection of the event. At first instance, he was found guilty. On appeal, however, medical examinations revealed that the accused was schizophrenic and was not in his right mind at the time of stabbing the deceased. A special finding of guilty but insane was made.

Expert evidence is admissible under Section 48 of the Evidence Act. ${ }^{44}$ Failure to include psychiatrists' expert testimony at this stage can easily lead to an injustice as almost happened in the 1983 case of Richard Kaitany Chemagong $v$ R. The

\footnotetext{
40 Section 2, Mental Health Act (2007).

41 WHO, 'Mental Disorders', http://www.who.int/topics/mental_disorders/en/ on 3 February 2016.

42 https://www.psychiatry.org/about-apa/read-apa-organization-documents-and-policies on 13 December 2016.

43 Leonard Mwangemi Munyasia v Republic 2015 eKLR.

44 Section 48, Evidence Act (Act No 46 of 1963).
} 
accused was headed for the gallows until when, on appeal, expert witnesses were consulted and it was discovered, upon medical examination, that the accused was actually mentally disabled.

Evidently, the courts are not medical experts and rely on the knowledge of experts in distinguishing between legitimate symptoms from spurious claims. ${ }^{45}$ As warned in Leonard Mwangemi Munyasia v Republic, every care ought to be taken to ensure that a mentally disabled person is not wrongfully punished.

\section{ii. Incapacity to understand what one is doing or that it is wrong}

Under this limb, the defendant must prove that at the time of crime, they were incapable of understanding what they were doing; or were unable to establish that what they were doing was wrong. Worth noting is that this limb is recognised in case law as applying to the accused's state of mind at the time of crime. Take X, for instance, who murders Y on Saturday, at the height of the effects of some 'disease of the mind'. $\mathrm{X}$ is arrested and subsequently arraigned in court on Monday. By this time, $\mathrm{X}$ is back to their senses. How do we then try X? In $\mathrm{R} v$ Martin Muriithi Mwongera, ${ }^{46}$ the accused attacked and killed his brother. He was found guilty. On appeal, he pleaded that he was sick on the material day and consequently did not appreciate the impact of his deeds. Medical examination found that though the accused had no history of mental disease, he was suffering from paranoia, hallucinations and flight of ideas on the material day. It was held that the prosecution had failed to prove malice aforethought. The offense was changed to manslaughter and the accused was found guilty. The court appreciated that the accused had now recovered and sentenced him to jail instead of making a special finding of guilty but insane.

Perhaps this is an embodiment of the 'benevolent conspiracy'47 said to be at work in courts as regards mental incapacity. However, this is not to say that every such plea is allowed. The drawn out case of Liundi $v$ Republic ${ }^{48}$ is an example of an instance where the court meted out its full wrath on one who relied on this defence. The accused poisoned both herself and her children after a domestic disagreement. Only she and one child survived, and she was indicted for murder.

\footnotetext{
45 Abrahamsen D, The mind of the accused; a psychiatrist in the courtroom, Simon and Schuster, New York, $1983,13$.

46 Rv Mwongera (2010) eKLR.

47 Baker D, Glanville Williams Textbook of Criminal Law, Sweet \& Maxwell, 4ed, London, 2015, 599.

48 Liundi v Republic (1976- 1985) EA 251.
} 
She pleaded insanity, claiming that she was not in her right frame of mind at the time of the act. Letters written by the accused stating that her husband was not to be blamed for the deaths were presented in court. This indicated that she was in fact aware of her actions. Medical evidence further indicated that though she had been stressed on the day of the incident, she knew exactly what she was doing and that it was wrong. Her plea of insanity was rejected.

\section{iii. Insane delusions}

Lastly, it must be proven that the accused was labouring under an insane delusion. A mental delusion, sometimes called partial insanity, ${ }^{49}$ is an insane belief which cannot be removed from the person's mind even by reasoning with them. Interestingly, the courts had previously been well acquainted with this form of mental incapacity. In the Hadfield case, defence counsel argued that 'delusion was the inseparable companion of real insanity' and subsequently managed to secure his client from the jaws of punitive law and delivered him instead into muchneeded medical care.

\section{iv. Limitations of the M'Naughten Rules}

In truth, the M'Naughten rules have been under criticism from the time they were formulated..$^{50}$ The criticisms have grown harsher with the advancement of psychiatry considering that the rules were formulated when psychiatry was still in its early stages. Some contemporary scholars have speculated that the revered M'Naughten rules are outmoded and it is just a matter of time before the courts do away with them. ${ }^{51}$ Richard Card gives a succinct summary of the main criticisms that have been made against the M'Naughten rules. ${ }^{52}$ They are discussed below, with emphasis laid on aspects which are of particular significance to Kenya.

\section{a) The $M^{\prime}$ Naughten rules are limited to cognitive factors}

The rules concern themselves only with cognitive matters and do not take into consideration emotions or volition. There have been cases in which medical evidence showed that the accused's inability to restrain an impulse was due to

\footnotetext{
49 Nyasani JM, Legal philosophy: Jurisprudence,Consolata Institute of Philosophy Press, Nairobi, 2001, 69.

50 Low, Jeffrieses, Bonnie, Criminal law, 656.

51 Ormerod, Smith and Hogan criminal law, 424.

52 In Card, Cross \& Jones criminal law, 622- 623.
} 
mental incapacity. In $R v$ Kopsch $b^{53}$ for instance, the accused admitted strangling the deceased. The psychiatric evidence was that the accused was acting at the direction of his subconscious mind. He was totally stripped of his self-control. The contention here was that if a disease so impairs the accused of his self-control it also severs his capacity to distinguish right from wrong. This argument was rejected as a 'fantastic theory... which if it were to become part of our law would be merely subversive'. ${ }^{54}$

In Kenya, the law that deals with impulsive acts is the defence of provocation. It has been held that provocation is subjective ${ }^{55}$ and so is generally governed by local legislation and not common law. ${ }^{56}$ However, the thought of including even the directions of one's subconscious mind as suggested in Kopsch would be overstretching its mandate. Such a formulation would undoubtedly require the expertise of psychiatrists.

\section{b) The 'delusion' branch}

It has been stated that some delusions ought not to be included in the rules, especially when they call into question whether the accused is culpable or not. The case of $R v$ Burgess $^{57}$ is a classic example of this dilemma. The accused was a sleepwalker. While asleep, he hit his friend on the head with a bottle and video recorder. He then grasped her around the throat. She cried out and he seemed to come to his senses, showing great anxiety. He was charged with wounding with intent. The court held that he lacked mens rea. Closer home, the Ugandan case of $\mathrm{R} v$ Magata s/o Kachehakana ${ }^{58}$ is similar. The accused believed that his father was Satan and murdered him. Here too the court held that the accused was not liable because he did not know what he was doing.

With that said, commentators maintain that the M'Naughten rules are more flexible in practice than they are at a mere reading of the law. ${ }^{59}$ It therefore emerges that on the whole, the substantive quality as pertains the M'Naughten rules is not only solid in letter ${ }^{60}$ but has a spirit that is alive to innovation and dis-

\footnotetext{
$\mathrm{R} v \operatorname{Kopsch}(1925)$.

$\mathrm{R} v$ Kopsch.

Rex vMusbibi s/ o Mubinguzi (1946) 13 EACA 139.

Rex v Hussein s/o Mobamed (1942) 9 EACA 52.

$R v$ Burgess (1991) The Court of Appeal of the United Kingdom.

R v Magata s/o Kachebakana (1957) EA 330.

9 T Ward, 'A Terrible responsibility : Murder and the Insanity Defence in England 1908-1939', 25 International Journal of Law and Psycbiatry, 2002, 361.

60 The mere fact that the rules remain applicable nearly two centuries after their formation. See Ormerod, Smith and Hogan Criminal Law, 416.
} 
covery, as can be seen in the courts' openness to include the less conventional yet newly proven mental conditions and illnesses. Cases involving conditions such as sleep walking, ${ }^{61}$ some effects of diabetes ${ }^{62}$ and even premenstrual syndrome ${ }^{63}$ have been admitted in court and received favourable address.

\section{Something Borrowed: Comparison to England}

Under this section, the paper examines the provisions of Kenyan law on the detention of mentally ill defendants and juxtapose it with the law as it stands in England. A study of the procedural law on detention is essential as provisions on detention may very well play a prodigious role in the defendant's willingness to even plead insanity in the first place. The comparison to England's position is a bid to provide an ideal which Kenya could borrow a leaf from where it is found that we are still lagging behind, especially in instances where the situation could be easily improved. Moreover, Kenya's law on insanity originated from England-being its former colonial master.

Today, in Kenya, there is a presumption of sanity ${ }^{64}$ and the sanity of an accused person can only come into question under two instances in criminal proceedings. First, the accused's mental condition can become a 'procedural bar'. ${ }^{65}$ This happens when the accused's mental condition is found to be so poor as to make him unfit to appear before court. ${ }^{66}$ It is generally accepted that such a person is unable to understand the charges against them and to participate in the proceedings. ${ }^{67}$ To carry on with the proceedings despite the accused's mental condition goes against the right to a fair hearing. Therefore, the general rule here is to postpone the trial. ${ }^{68}$ It may also be determined during trial that the accused's mental condition renders him unfit to be tried. ${ }^{69}$ Similarly, the court has to postpone further proceedings.

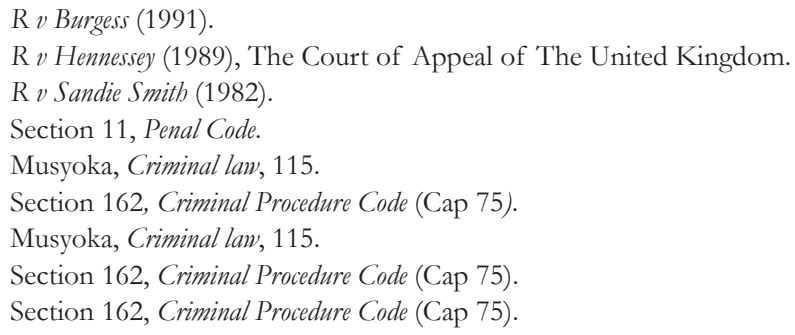


What is under scrutiny here is what exactly becomes of the defendant if found to be unfit to make his defence. Section 162 of the Criminal Procedure Code provides for the disposal of such persons. There are different provisions given for bailable and non-bailable ${ }^{70}$ offences as discussed below.

Procedure to be followed for bailable offences as per section 162 (2) of the Criminal Procedure Code is as follows:

'If the case is one in which bail may be taken, the court may release the accused person on sufficient security being given that he will be properly taken care of and prevented from doing injury to himself or to any other person, and for his appearance before the court or such officer as the court may appoint in that behalf.'

Where, however, the offence is non-bailable, or the said 'sufficient security' is not given, the court is to order for the detention of the accused in such a place that it will deem fit. The court record is then transmitted to the Attorney General for consideration by the President. There are two matters of consideration that arise from this section. First, the new Constitution guarantees the right to bail to all arrested persons, regardless of the offence committed. This means 'bailable' and 'non-bailable' offences are now obsolete. ${ }^{71}$ There is therefore a gap in the law, and there is need to reform this section so as to meet the purposes of balancing the rights of the accused to bail and the interests of the public, who may be in danger of further harm.

Secondly, it is not lost on the reader that once one is determined to be mentally ill, the matter immediately falls under the authority of the President. This 'transfer' will be expounded on further momentarily.

Other than being a procedural bar, insanity can also be proven at the determination of the case. A defendant who satisfies the M'Naughten rules is given a special finding of guilty but insane. The person is said to be guilty of the act or omission but insane at the time of crime. After this, the Criminal Procedure Code comes in swiftly and whisks the accused off to the mercy of the President. As some scholars have commented, the court that has interacted with the accused is granted no discretion in their sentence or freedom. ${ }^{72}$ The paper considers each of these steps singularly:

\footnotetext{
${ }_{70}$ These were formerly murder, treason, robbery with violence, attempted robbery with violence and any drug related offence. Section 123, Criminal Procedure Code (Cap 75).

71 Article 2(4), Constitution of Kenya (2010).

72 Lumumba, $A$ bandbook on criminal procedure, p. 16.
} 


\section{i. Guilty but insane}

This special finding has its origins in early cases such as M'Naughten and the later yet similarly sensational case of Ronald True. ${ }^{73}$ Article 166 (1) of the Criminal Procedure Code provides: 'the court shall make a special finding to the effect that the accused was guilty of the act or omission charged but was insane when he did the act or made the omission.' A 'special' verdict is that which includes a statement as to how the verdict has been reached. In the case of insanity for instance, the verdict is 'guilty but insane' as opposed to just 'guilty', which is a general judgement.

The special finding ensures that insane offenders who are found to be a potential threat to the security of other members of society are placed at bay. Moreover, it promotes deterrence.

\section{ii. Detention}

Section 166 of the Criminal Procedure Code states the following:

When a special finding is so made, the court shall report the case for the order of the President, and shall meanwhile order the accused to be kept in custody in such place and in such manner as the court shall direct. (3) The President may order the person to be detained in a mental hospital, prison or other suitable place of safe custody.'

The disposal of persons found to be guilty but insane is perhaps what makes the defence so unattractive. Not only is one prone to stigma due to the 'insanity' label, ${ }^{74}$ but one is also sure of an indefinite detention. Findings show that persons who would have qualified for the defence have shied away from the defence and instead chosen to subject themselves to prison life, where they are sure of the amount of time they are likely to spend there. ${ }^{75}$

73 Ronald True was a drug addict from an influential family in England. His behaviour grew more eccentric over time to the extent of believing that he had a 'doppelganger' that hated him passionately. However, he had never been hospitalised on account of his mental issues. He was indicted for killing a woman and stealing her money and was found guilty but was pardoned by then Secretary of State Edward Shortt and subsequently spent the remainder of his days in an asylum. $R v$ Ronald True, 16 Cr. App.R. 164 (1922).

74 Moresby White argues the opposite, stating that the insanity label actually removes the stigma associated with guilty findings. 'Legal insanity in criminal cases past, present and future' 18(2) Journal of Criminal Law and Criminology, 1927, 174.

75 As was the case in England before reforms were introduced. See Griew EJ, 'Let's implement butler on mental disorder crime', (1984). 
Furthermore, the President is once again granted unconventional and controversially discretionary powers in determining the detention of the accused. It is rather interesting to note that this particular function is not listed under Articles 132 and 133 of the Constitution. This power might be speculatively inferred from the President's power of mercy provided for under Article 134, but that would be at the very least merely reading between the lines.

Several matters hang in the balance if we choose to carry on with the law as it stands. First, with no clear guidelines as to how to determine where an accused person is detained, there is risk of detaining mentally ill patients in prisons where they are less likely to access the treatment they need as opposed to a health facility. Second, it is not for naught that the saying 'power corrupts' remains popular. Vesting such discretionary powers in the presidency, not being medical nor judicial in composition, could lead to abuse.

As already discussed, the English law on insanity as we know it today was birthed by insecurity concerns caused by people who were then considered deluded..$^{76}$ They were considered dangerous and the simplest available solution was confinement in a mental institution. For a long time, the only disposal method available was indefinite detention, ${ }^{77}$ possibly a reflection of the origin of Kenya's own law. In fact, this changed in 1991 with the Criminal Procedure (Insanity and Unfitness to Plead) Act. Like Kenya, England maintains the special verdict. However, the options available are wider. They include a hospital order, a supervision order and an order for complete discharge.

\section{Something New: A Possible Marriage}

A promising solution to the quandary that surrounds insanity in the law would be the marriage of psychiatric expertise and legal authority ${ }^{78} \mathrm{At}$ first, it seems almost obvious: the psychiatrist, being well-qualified to do so, would examine the offender and pronounce him ill or not, and the courts would then give its judgement based on the advice received. As simple as that arrangement sounds, it also presents a problem: how do we achieve such a mechanism while

\footnotetext{
76 Loughman A, Manifest Madness; Mental Incapacity in Criminal Law, Oxford University Press, Oxford, 2012, 167.

77 Ormerod, Smith and Hogan Criminal Law, 425.

78 Moenssens AA, Henderson EC, Portwood SG, Scientific Evidence in Civil and Criminal Cases, Foundation Press, Thomson West, 5ed, 1259.
} 
avoiding the creation of a clear state of tyranny? ${ }^{79}$ Moreover, the idyllic co-existence between the two professions in countries that already implemented this is nowhere near in sight. The relationship is riddled with tensions between the two camps, not to mention the in-house debates on insanity that have been raging for decades now. ${ }^{80} \mathrm{~A}$ more complex solution, one that is considerate of the danger of tyranny and the fundamental differences between the two professions is needed.

Lawyers have essentially looked down on psychiatry, arguing that it is not 'really a science', ${ }^{81}$ and that psychiatrists actually hinder rather than assist in the attainment of justice. ${ }^{82}$ Psychiatrists on the other hand can hardly put up with the legal definition of terms used, let alone the tests applied to arrive at a conclusion on a defendant's state of mind. To them, lawyers, no matter how well trained in the law, are still laymen in psychiatry. ${ }^{83}$

However, it is argued here that the tension between the two schools has nothing to do with the weakness of one but, rather, has everything to do with the merits of both. It is out of the professions' different philosophical underpinnings, training and methods that the uncomfortable situation is borne. Seymour Halleck summarises the dilemma concerning the law and psychiatry thus:

'Because our society cannot afford to redefine crime as an illness, criminology will not and should not become a sub-speciality of psychiatry. Still, the suffering of the criminal and the havoc he creates throughout the community will often call for the services of the psychiatric profession. ${ }^{94}$

This is especially true where mental illnesses somehow find themselves the subject of the issues being argued over by a prosecutor and a hypercritical defence lawyer. It therefore follows that, somehow, the law has to carve out a space sufficient enough for appropriate psychiatric intervention.

\footnotetext{
79 Experts maintain that tyranny is a potential danger whenever expert skill is required of other professions in the dispensation of justice. The concern is that though reliance on these fields is unavoidable, the force given to experts can easily be used 'for evil' with dire consequences. See Germann AC, Day FD and Gallati RJ, Introduction to law enforcement and criminal justice, 24ed, Charles C Thomas, Illinois, 1973, 409. As seen, among psychiatrists, in the varying opinions it is possible to get concerning a single case. Moenssens AA, Henderson EC and Portwood SG, Scientific evidence in civil and criminal cases, 1255. Moenssens AA, Henderson EC and Portwood SG, Scientific evidence in civil and criminal cases, 1255. Karpman B, 'On reducing tensions and bridging gaps between psychiatry and the law' 48(2) Journal of Criminal Law and Criminology, 1957, 1.

84 Williams RH, To live and die: Where, when and how.
} 
On the other hand, Kenya still has smaller hurdles to overcome before the two professions can even have the leisure to begin bickering over brain-racking philosophical and clinical incidentals. The first challenge that we are faced with here is the deplorable standards of mental health care in Kenya. As it stands, the Kenyan mental health sphere is badly under-staffed with scant resources. ${ }^{85}$ Even the country's largest public mental health hospital, Mathari, is affected and has been making the news for all the wrong reasons. ${ }^{86}$ With such problems, it is evident that mental healthcare conditions must first be elevated. That will be the first practical step toward creating a culture of collaboration and more importantly, quality care for our sick.

In Kenya, a psychiatrist is a fully qualified and duly registered doctor with a Master's Degree in Psychiatry. According to the University of Nairobi, the Masters programme 'shall consist of a three-year fulltime study by clinical work, coursework, dissertation and examination, and at least two of these three years must be spent in a medical institution in East Africa, recognised by the University of Nairobi'. ${ }^{87}$ Psychiatrists are trained in the 'diagnosis, treatment and prevention of mental, emotional and behavioural disorders'.

Two suggestions are made in this vein. First, scholars on both ends have asserted that the core issues at deliberation ought to be made relevant to the psychiatrist in expecting his/her to answer certain questions. ${ }^{8}$ This is because to the psychiatrist, the accused is nothing less than a possible patient. The court therefore has to be deliberate in its expectations of the expert witness. Failure to do so would easily amount to a situation where the psychiatrist's evidence is lost in explaining terms. ${ }^{89}$ As earlier stated, the legal terms used currently have little significance to the psychiatrist. Second, the questions asked ought to be medically viable, in that the psychiatrist can answer them with 'reasonable estimates'. ${ }^{90}$

85 https://in2mentalhealth.com/2013/02/14/eight-encounters-with-mental-health-care-kenya/ on 13 December 2016.

86 Ngirachu J, 'Mathari Hospital Hit by Congestion Crisis', Daily Nation, 4 April 2016; 'Mental Patients Escape From Mathari Hospital as Doctor Strikes Begin,' Standard Digital, 5 December 2016. https://www.standardmedia.co.ke/health/article/2000225842/mental-patients-escape-matharihospital-as-doctors-strike-begins on 12 December 2016.

87 Available at http://www.mastersportal.eu/studies/96965/psychiatry.html (accessed in August 2016)

88 Moenssens AA, Henderson EC, Portwood SG, Scientific Evidence in Civil and Criminal Cases, 1256.

89 Kerper H, Introduction to the criminal justice system.

90 Kerper H, Introduction to the criminal justice system. 


\section{Recommendations}

In view of the difficulties surrounding the very idea of the defence of insanity coupled with the shortcomings present in our system, it is evident that Kenya has a long road ahead in the journey to bring some harmony to the still discordant laws and views on insanity. One direction that could be taken is to completely scrap the defence, as some have suggested; but that would leave a vacuum as to how to manage mentally ill persons in certain situations.

A different approach is to keep the insanity defence but to tighten the loose ends that act as impediments. The disrespectful manner in which mentally ill persons are referred to in some legislations; particularly those that have not been reviewed in a while ought to be corrected. The task falls under The Kenya Law Reform Commission (KLRC) established by the Kenya Law Reform Commission Act, No. 19 of 2013.

Further, regulations as to psychiatric involvement in mental incapacity cases ought to be put in place to ensure uniformity. In England, for example, the law is that a special verdict cannot be given without giving the opinion of at least two psychiatrists. This is not to say that England's position on the matter is without faults, but to demonstrate that guidelines on how to employ expert witnesses are needed.

Public mental health care institutions should by way of law be established at both levels of Government so as to ensure that treatment is affordable and accessible to even the common mwananchi. Moreover, this will aid in solving the problem of detention of persons with mental illness as health institutions that cater to their needs will be at the disposal of the courts.

Another area that could do with legal reform is the law regarding detention of defendants with mental illness. It is the position of this paper that the Criminal Procedure Code gives too much discretion to the President by empowering the sovereign to even determine the place where mentally ill offenders are to be incarcerated. Given the historical foundations of this tenet as demonstrated elsewhere in this paper, it seems almost absurd that the code has not yet been amended so as to give more specific directions as to disposal. Such a situation is ripe for abuse, as power is wont to corrupt. A system of accountability and transparency ought to be implemented instead. In this vein, it is suggested that a committee be established to serve an advisory role, similar to the Advisory Committee on the Power of Mercy. 


\section{Conclusion}

All in all, the discourse on insanity in the law is a difficult one, yet one that legal practitioners will have to grapple with for years to come just as their predecessors did. This is because it seems to be the way of nature that once in a while, the presumption of sanity present in the law will be undoubtedly proven wrong for some individuals. What society chooses to do with these individuals, history has shown, is a matter of legal permissibility. Our ancestors drilled holes into their heads in a period where sedation was unknown. Later, they abandoned them in asylums where the queerest practices were performed on them in the hope of curing them. Now, we speak of human rights and dignity. We speak of scientific innovation and the role it has played in making the world a better place. Yet, after all our talk of grandeur, much remains to be done in the systems that we have put in place for persons with mental illness. 